\title{
БЮДЖЕТНА ПІДТРИМКА БУДІВНИЦТВА ДОСТУПНОГО ЖИТЛА ДЛЯ НАСЕЛЕННЯ В УМОВАХ ДЕЦЕНТРАЛІЗАЦІї
}

\author{
Возняк Галина Василівна \\ доктор економічних наук, провідний науковий співробітник \\ ДУ «Інститут регіональних досліджень ім. М.І. Долішнього НАН України» (м.Львів, Україна) \\ ORCID: 0000-0003-2001-0516 \\ gvoznyak@gmail.com

\section{Коваль Василь Михайлович голова Підберізцівської ОТГ (с. Підберізці, Україна)}

В статті розкрито особливості бюджетної підтримки будівництва доступного житла для населення в умовах поглиблення реформи адміністративно-фрінансової децентралізації. Виявлено низку дестимулюючих чинників реалізації державної житлової політики, а саме: недоступність іпотеки для більшості громадян, неефективність державних пільгових житлових програм, недосконалі механізми розподілу бюджетних коштів, надто громіздкий порядок отримання пільгових кредитів, необгрунтовано висока вартість житла, орієнтація на заможного споживача тощо. Визначено напрям активізації будівництва доступного житла для населення. Показано, що альтернативним інструментом бюджетному фрінансуванню будівництва житла може слугувати державно-приватне партнерство.

Ключові слова: доступне житло, бюджетна підтримка, адміністративно-фрінансова децентралізація, якість життя, бюджетне фрінансування.

DOI: https://doi.org/10.32845/bsnau.2019.1.12

Постановка проблеми. Житлова забезпеченість населення є однією із вагомих соціальних проблем сучасної України. Існуючий ринок житла, в переважній більшості, доступний для громадян з високим рівнем доходів. Це з одного боку. 3 іншого, високі процентні ставки за іпотечними кредитами комерційних банків унеможливлюють їх отримання для вирішення житлових питань. Очевидно, що значна частина населення, в тому числі молоді сім'ї, які потребують поліпшення житлових умов, не в змозі вирішити самотужки власні житлові питання. 3 огляду на зазначене, особливої гостроти набувають питання активізації та вдосконалення існуючих механізмів державної підтримки будівництва та придбання житла, позаяк житлове питання є стимулюючим чинником покращення якості життя населення, а відтак і демографічної ситуації загалом. Зазначимо, що однією із ключових цілей реформи адміністративно-фінансової децентралізації $€$ покращення соціальних стандартів життя населення.

Аналіз останніх досліджень $і$ публікацій. Окреслена тематика є предметом наукових пошуків низки вітчизняних науковців. Так, вивченню питань різних форм інвестування житлового будівництва за принципом розосередження ризиків переймалися Кравченко В. та Полівода К.[1]; теоретичні основи цього напряму знань сфрормовано працями Прокопенко В. [2], Вороніна В. [3]; тематиці регулювання інвестиційно-житлових відносин в Україні та висвітленню регіональних особливостей розвитку ринку нерухомості присвячені праці [4-5]. Систематизація наукового доробку з досліджуваної проблематики свідчить про те, що питання бюджетної підтримки будівництва доступного житла для населення в умовах поглиблення децентралізації влади та ресурсів потребують додаткового вивчення.

Метою cmammi $є$ аналіз сучасних тенденцій, виявлення ключових проблем державної підтримки будівництва житла та обґрунтування напрямів їх розв'язання в умовах децентралізації влади та ресурсів.

Основні результати дослідження. Сучасний етап розвитку економіки України характеризується, з одного боку, зміщенням акцентів в напрямі адміністративно-фінансової децентралізації з одночасною передачею ресурсів, повноважень та відповідальності на місця, з іншого - передбачає ефективне використання внутрішнього потенціалу територій, оптимізацію системи влади та недопущення зростання територіальних асиметрій.

В контексті зазначеного житлове будівництво $є$ одним із пріоритетних видів економічної діяльності, бо воно може слугувати механізмом стимулювання економічної активності в суміжних галузях, а відтак і виконує важливу соціальну функцію. Однією із цілей реформи адміністративно-фінансової децентралізації $€$ безпечне та комфортне середовище для життя людини в умовах прозорих механізмів розвитку будівельної галузі, безпечний та гармонійний просторовий розвиток громад. Потрібно відмітити, що в цьому напрямі за час впровадження реформ відбулися помітні зрушення, які дали змогу: спростити процедури у сфері будівництва (у 2019 році, за рейтингом Doing Business, за напрямом «Отримання дозволів на будівництво» Україна піднялась на 30 місце із 140 в 2017 році [6]); удосконалити дозвільні процедури видачі будівельного паспорта забудови земельної ділянки; в частині технічного регулювання вдосконалено положення державних будівельних норм (далі - ДБН) з урахуванням сучасних технологій, що дозволило виключити із будівельних норм положення, які $€$ предметом регулювання нормативно-правових актів, та положення, які не відповідають міжнародно визнаним принципам нормування у будівництві тощо.

Такі позитивні зміни в Україні обумовили пожвавлення житлового будівництва, причому незмінною за період 2013 2017 рр. є стійка тенденція перевищення кількості збудованих квартир над введеними в експлуатацію (табл.1). До слова, за перше півріччя 2019 року прийнято в експлуатацію 4911,2 тис. кв. м загальної площі житлових будівель (нове будівництво), що на 50,6\% більше в порівнянні із періодом попереднього року. Лідерами серед регіонів були: Київська область (не враховуючи міста Києва) - 684,3 тис. кв. метрів (на 
15,2\% більше, ніж торік); друге - Львівська (632,9 тис. кв. метрів; на 69,9\% більше); третє - Одеська (474,8 тис. кв. метрів; на 113,1\% більше) області. Найменше новозбудованого житла у січні-червні 2019 року було прийнято в експлуатацію у Луганській (9 тис. кв. метрів; на 67,9\% більше, ніж торік), Донецькій (27 тис. кв. метрів; на 97,3\% більше) та Миколаївській (37,8 тис. кв. метрів; на 106\% більше) областях [7].

Розподіл кількості збудованих та прийнятих в експлуатацію житлових будівель, 2013-2017 рр.

\begin{tabular}{|c|c|c|c|c|c|c|}
\hline Рік & $\begin{array}{l}\text { Збудовано } \\
\text { квартир, } \\
\text { од }\end{array}$ & $\begin{array}{c}\text { На } 1000 \\
\text { постійного } \\
\text { населення, од }\end{array}$ & $\begin{array}{c}\text { Прийнято в } \\
\text { експлуатацію, } \\
\text { од }\end{array}$ & $\begin{array}{c}\text { Загальна площа прийнятого } \\
\text { в експлуатацію житла, } \\
\text { тис. кв. м }\end{array}$ & $\begin{array}{c}\text { Загальна площа } \\
\text { прийнятого в } \\
\text { експлуатацію житла, } \\
\text { тис. кв. м за рах. ДБ }\end{array}$ & $\begin{array}{c}\text { \% до загального } \\
\text { обсягу }\end{array}$ \\
\hline 2013 & 92612 & 2,2 & 28968 & 9949 & 50 & 0,5 \\
\hline 2014 & 105241 & 2,5 & 21602 & 9741 & 33 & 0,3 \\
\hline 2015 & 120307 & 2,8 & 28853 & 11044 & 53 & 0,5 \\
\hline 2016 & 112576 & 2,6 & 21243 & 9367 & 30 & 0,3 \\
\hline 2017 & 125610 & 3,0 & 22906 & 10206 & $\ldots$ & $\ldots$ \\
\hline
\end{tabular}

Натомість, за оцінками Національного банку України «жвавіший попит зумовлений переважно зростанням доходів населення. Адже, на думку учасників ринку, кредити банків фінансують менше 7-8\% угод первинного продажу житла, на вторинному ринку ця частка ще нижча, обсяги іпотечного кредитування зростають, проте ще замалі, щоб помітно впливати на ринок житлової нерухомості. Імовірно, в середньостроковій перспективі іпотечне кредитування не буде визначальним на ринку житлової нерухомості» [8].

За таких умов проблема забезпечення населення доступним житлом, особливо для малозабезпечених, внутрішньо переміщених осіб, громадян, які постраждали внаслідок АТО на сході України тощо, не втрачає своєї актуальності. В цьому сенсі Україна і надалі поступається за показниками забезпечення населення загальною житловою площею та розміром квартир в розрахунку на особу країнам з розвиненою економікою. Справедливості ради зазначимо, що впродовж останніх років стійкою $є$ тенденція до будівництва одно та двокімнатних кватир невеликої площі, що дещо понижує рівень комфортності такого житла, що в підсумку не сприяє досягненню цілей адміністративно-фінансової децентралізації. Незважаючи на низку заходів, яких вживають органи влади різних рівнів для розв'язання житлової проблеми, наразі вона й надалі продовжує бути на порядку денному.

В Україні прийнято низку бюджетних програм, які покликані сприяти створенню умов для розвитку будівництва доступного житла та забезпечення фрінансовою підтримкою громадян, що потребують поліпшення житлових умов та здійснюють відповідні інвестиції у будівництво такого житла, а саме на загальнодержавному рівні: «Надання пільгового довгострокового державного кредиту молодим сім'ям та одиноким молодим громадянам на будівництво (реконструкцію) та придбання житла»; «Надання державної підтримки для будівництва (придбання) доступного житла»; «Доступне житло»; «Субвенція з державного бюджету місцевим бюджетам на будівництво (придбання) житла для сімей загиблих військовослужбовців, які брали безпосередню участь в антитерористи- чній операції, а також для інвалідів I-ІІ групи з числа військовослужбовців, які брали участь у зазначеній операції, та потребують поліпшення житлових умов», «Фінансова підтримка Державного фонду сприяння молодіжному житловому будівництву», «Здешевлення вартості іпотечних кредитів для забезпечення доступним житлом громадян, які потребують поліпшення житлових умов» і ін. Програми («Доступне житло», «Кредит із статутного капіталу»), які сприяють молодіжному житловому будівництву реалізує спеціально створена КМУ Державна спеціалізована установа «Державний фонд сприяння молодіжному житловому будівництву». На обласному рівні (станом на 2018 рік їх було понад 70), в межах існуючих фінансових можливостей, формуються різні цільові програми державної підтримки громадян у їх прагненні отримати власне жило.

Прийняті не завжди означає виконані (причини різні від дефіциту коштів на їх фінансування, до недосконалих процедур їх розподілу). До слова, фінансування державної соціально-економічно цільової програми будівництва (придбання) доступного житла на 2010-2017 рр., яка надавала іï учасникам 30-відсоткову (для певних категорій 50-відсоткову) державну допомогу на придбання житла, було повністю припинено, починаючи із 2015 року (рис1).

Тільки у 2018 році цю програму було «реанімовано», шляхом: а) передбачення на неї фінансування в бюджеті (100 млн грн) та б) удосконаливши процедуру участі громадян в ній (спрощено процедуру відбору житлових об'єктів - одержувачі державної підтримки самостійно обирають об єкти, на будівництво яких можуть спрямовуватися кошти державної підтримки, а також новозбудовані об єкти; удосконалено механізм розподілу бюджетних коштів, що здійснюється Мінрегіоном між адміністративно-територіальними одиницями пропорційно чисельності населення, яке проживає у відповідному регіоні; врегульовано питання роботи комісії Мінрегіону з розгляду пропозицій щодо формування переліку осіб, які претендують на отримання державної підтримки). В межах цієї програми держава змогла компенсувати частину вартості квартир для 88 сімей. 


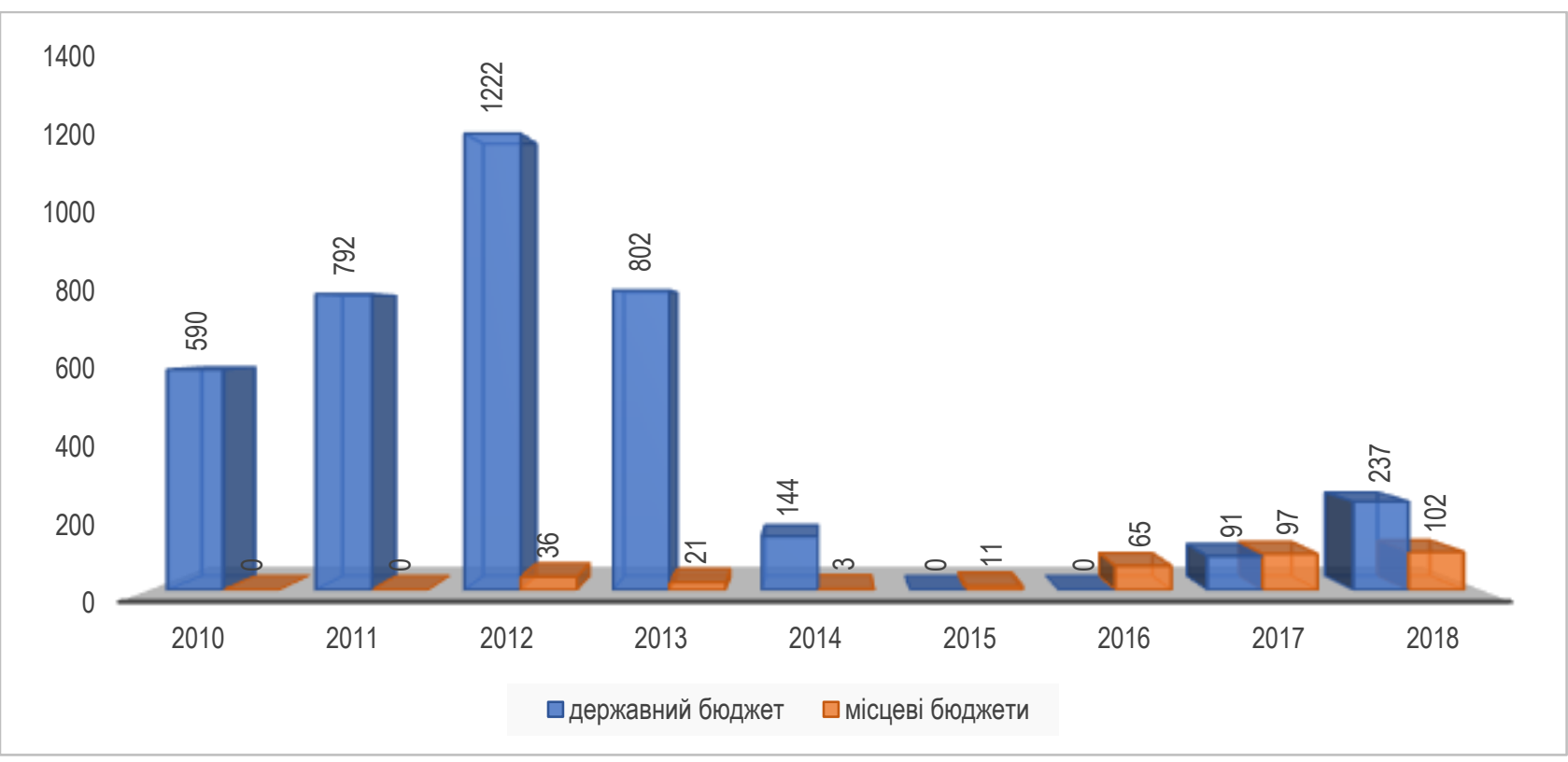

Рис.1 Кількість квартир, отриманих громадянами в рамках бюджетної програми будівництва (придбання) доступного житла Складено з використанням даних Міністерства розвитку громад та терuторій. URL: http://www.minregion.gov.ua/press/prezentatsiynimateriali/?fbclid=IwAR2WA3ZyGofdZ_qTcnj4wVQNEZ7nhRF9JnWrFL2K4YE1LnQmc7h9-Ja4rijQ

Інша державна програма («Пільгового молодіжного кредитування»), метою якої є створення належних умов для забезпечення молодих сімей та одиноких молодих громадян житлом, яка діє з 2002 року передбачала виділення коштів для надання пільгових кредитів на будівництво (реконструкцію) та придбання житла у розмірі 1397 млн грн. По факту профінансовано із загального фонду державного бюджету 609 млн грн. За рахунок місцевих бюджетів було заплановано профінансувати з 2002 по 2012 роки 1060 млн грн, натомість профінансовано 352 млн грн. Загалом за цей період було надано 7318 пільгових довгострокових кредитів молодим сім'ям та одиноким молодим громадянам на будівництво (реконструкцію) та придбання житла, збудовано та введено в експлуатацію 691 будинок загальною кількістю 38687 квартир та загальною площею 2835,5 тис. кв. метрів (в яких отримали квартири 7083 молоді сім'ї) [9]. Починаючи з 2013 року фінансування цієї програми суттєво погіршилося (скоротилось до 11,3\% від плану), а в 2015-2016 рр. взагалі припинилось (часткове фінансування було тільки за рахунок коштів місцевих бюджетів).

Аналіз таких державних програм можна й далі продовжувати, але очевидним є одне - картина буде схожою. В цілому, існуюча в Україні система пільгового фрінансування житла не відповідає очікуванням населення на поліпшення житлових умов, державні програми важко назвати ефективним механізмом вирішення житлової проблеми (в силу різних причин та підходів до їх реалізації, неможливості охопити усіх категорій громадян, які потребують поліпшення житлових умов, а най головне - хронічне недофінансування). Зазначене обумовлює об'єктивну потребу в перегляді механізмів сприяння житловому будівництву та контролю за їх виконанням.

Висновки. Проведене дослідження дало підстави стверджувати, що в Україні проблема будівництва доступного житла, попри позитивні зрушення, які намітились в даній сфері в останні 2-3 роки, й надалі залишається не вирішеною. Недоступність іпотеки для більшості громадян, неефективність державних пільгових житлових програм, недосконалі механізми розподілу бюджетних коштів, надто громіздкий порядок отримання пільгових кредитів, необґрунтовано висока вартість житла, орієнтація на заможного споживача тощо невеликий перелік дестимулюючих чинників у сфері реалізації державної житлової політики. Зазначене обумовлює необхідність вироблення нових та вдосконалення існуючих механізмів вирішення досліджуваної проблеми. На наше переконання, в умовах посилення реформи адміністративно-фінансової децентралізації, альтернативним інструментом бюджетному фінансуванню будівництва житла може слугувати державно-приватне партнерство, в силу того, що воно може забезпечити стабільне фінансування, розподіл та мінімізацію ризиків, в процесі будівництва застосовує новітні підходи до управління проектами тощо. Зрозуміло, що нові умови та нові виклики обумовлюють необхідність перегляду організаційноекономічних засад забезпечення ефективної діяльності учасників даного процесу.

\section{Список літератури:}

1. Кравченко В.І., Полівода К.В. Фінансування будівництва житла: новітні тенденції. Київ, 2006. 173 с.

2. Прокопенко В. Ю. Фінансово-кредитні інструменти на ринку нерухомості: теорія та практика: монографія / В. Ю. Прокопенко. Х.: ВПП «Контракт». 2012. 416 с.

3. Воронін В.О. Аналітика ринку нерухомості: методологія та принципи сучасної оцінки: монографія . В.О. Воронін, Е.В. Лянце, М.М. Мамчин. Львів: видавництво «Магнолія 2006». 2014. 304 с.

4. Павлов К.В. Регулювання інвестиційно-житлових відносин в Україні : монографія / К.В. Павлов. Рівне: НУВГП, 2013. $230 \mathrm{c}$.

5. Стрішинець О. М. Особливості конкурентних відносин на регіональних ринках нерухомості / О. М. Стрішинець, К. В. 
Павлов // Науковий вісник Ужгородського університету. Серія: Економіка. - 2016. - Вип. 1(2). - С. 35-38.

6. Doing Business 2019 - http://www.doingbusiness.org/content/dam/doingBusiness/media/AnnualReports/English/DB2019-report_web-version.pdf.

7. Державна служба статистики. URL: http://ukrstat.gov.ua.

8. Національний банк України. Звіт про фінансову стабільність. URL: https://bank.gov.ua/control/uk/publish/category?cat_id=32236491

9. Постанова КМУ від 24.10.2012 №967 «Про затвердження державної програми забезпечення молоді житлом на 2013-2020 років». URL: https://zakon2.rada.gov.ua/laws/show/967-2012-\%D0\%BF

Voznyak H.V., Dr, Leading Researcher, State institution «Institute of Regional Research named after M.I. Dolishniy of the NAS of Ukraine» (Lviv, Ukraine)

Koval V.M., (Pidberiztsi, Ukraine)

Budget support for the building affordable houses for the population in conditions of decentralization

Improving the quality of life of population, safe and comfortable environment for human life in the context of transparent mechanisms for the development of the building industry, safe and harmonious development of communities are goals of the reform of administrative and financial decentralization. From these points of view, the issue of revitalization and improvement of the existing mechanisms of state support for the construction and purchase of housing is a relevant area of modern researches.

The purpose of the article is to analyze current trends, identify key problems of state support for housing construction and justify the directions of their solution in the conditions of decentralization of power and resources.

The article describes the peculiarities of budget support for affordable housing for population in context of deepening the reform of administrative and financial decentralization. It is shown that the positive changes in housing market that have been observed in recent years in Ukraine are due to both the consequences of the reform and the increase in household income. Mortgage lending isn't a determining factor in the revitalization of housing. A number of discouraging factors for the implementation of state housing policy have been identified, for example: unavailability of mortgages for the majority of citizens, inefficiency of state preferential housing programs, imperfect mechanisms of budget allocation, excessively cumbersome order for obtaining preferential loans, unreasonably high value for money. The direction of activation of affordable housing for the population has been determined. It has been shown that public-private partnership can be served as an alternative tool for budget financing of housing construction.

Key words: affordable housing, budget support, administrative and financial decentralization, quality of life, budget financing

Дата надходження до редакції: 16.11.2018 р. 